\title{
「身の回りのマイクロ・ナノ技術」 特集号発刊に際して
}

\author{
Micro-Nano Technology for Our Daily Life
}

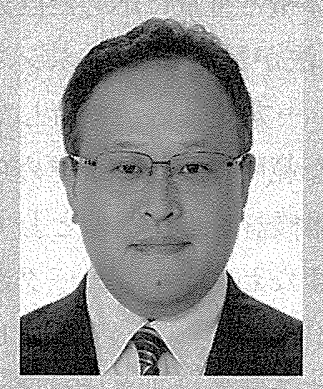

秦 誠一

\section{Seiichi HATA}

(0) 1994 年東京工業大学総合理工学 研究科精堂機械システム尃攻修 士課程修了, 1994 年オリンパス 光学工業 (株) 入社, 1997 年東 京工業大学精密工学研究所助手, 2002 年博I (I学)，2005 年同 大学フロンティア研究センター 助教授、2008 年東京工業大学精 密工学研究所准教授、2012 年 10 月より現職

○研究・尃門テーマは、ママイクロシ ステムおよひその材料，微細成 形加工，コンビナトリアル技衍 (C)正員, 名古屋大学教授 大学院I 学研究科 マイクロ・ナノシス \% 4 I学専攻

( 4 464-8603 名古屋市千種区不 老町

E-mail : hata@mech.nagoya-u. ac.jp)

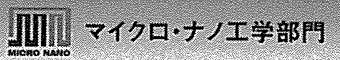

単結晶ンリコンの微細加工性やその物性がら、ンリコンが微小機械の材料たる ことを示した K. Petersen の歴史的なレビューから 6 年後, 1988 年，シリコンフ ロセスの応用で，微小な菊車やリンク機構を製作できるというカリフォルニア大 学バークレイ校の L. S. Fan らが示した可能性は, 大さな衝撃をせ界に与え MEMS の研究ブームが始まつた. 世界初の MEMS は何であるか議論が分かれる ところたが，上記の研究ブームに先駆けること 25 年前の 1963 年には (株) 豊田 中央研究所により半導体圧力七ンサが発表され，1967年には H. C. Nathanson に よる Resonant Gate Transistor が発表されている．1974年には谷回紀男がナノテク ノ日シーの概念を発表し、この日本発の造語は, もはや辞書に載るまでになった。

ナノテクノロジーの提唱や. MEMSの研究ブームから数十年の時が過ぎ，今 やナノテタノロジーはCMなとで常的に耳にする言葉となった．MEMSを始 めとするマイクロマシニングにより製作されたデバイも、目常製品の多くに組 み迄まれ，それらの搭載された製品に知らぬうちに触れ，その恩患に浴すことは 珍しくなくなった、つい最近までSFの世界であったカプセル内視鏡も製品化さ れた. スマートフォンやゲーム機に当たり前に搭載されるようになったモーショ

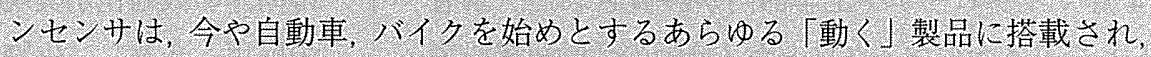
新しい「産業の米」になるうとしている．このように, MEMS,ナノテクノロジー に代表されるマイクロ・ナノ技術は，すでに最先端の研究ナーマだけてなく，さ まざまな民生品に応用されている

ここで注目したいのは，前述のナノテクノロジーという概念も、世界初の MEMSのーつであると言われる半導体厘力七ンサ 目本発だということである.

閉塞感や経済力の低下ばかり強調される昨今であるが, 先見的, 先進的なコンセ プトは必す生さ残り発展するという証左であると思う.大切なのは論理的，技術 的裏つけと想像力，生み出したコンセプトを実現する覚悟だと確信する。.

このような光景が広がる2012 年に目本機械学会に 21 番目の部門としてマイク ロ・ナノエ学部門が発足したことは，ある意味必然と言えるかもしれないてそこ で本特集で，最先端の研究内容からコンビコエンスストアにも壳っている身近 な製品まて，マイクロ・ナノ技術全体を俯瞰的に広く紹介するとともに，令後の 展開を幅広く概説することで, これまでとこれがらのマイクロ・ナノ技術の発展 に思いを巡らせ、新たな創造の一助になればと考え企画した。

最後に，ご多忙中にもかかわらず本企画への参加をお引き受けいただきました 執筆者各位，企画委員会委員各位なならひに学会事務局ほか，関係各位に心から 感謝申し上げる。

(原稿受付 2012 年 11 月 12 日)

2013 年 1 月号 [身の回りのマイクロ・ナノ技術」特集号企画小数会：主查 秦 誠一（名古屋

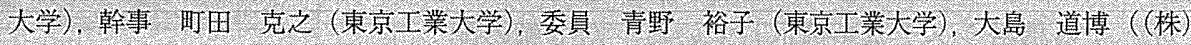

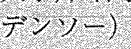

